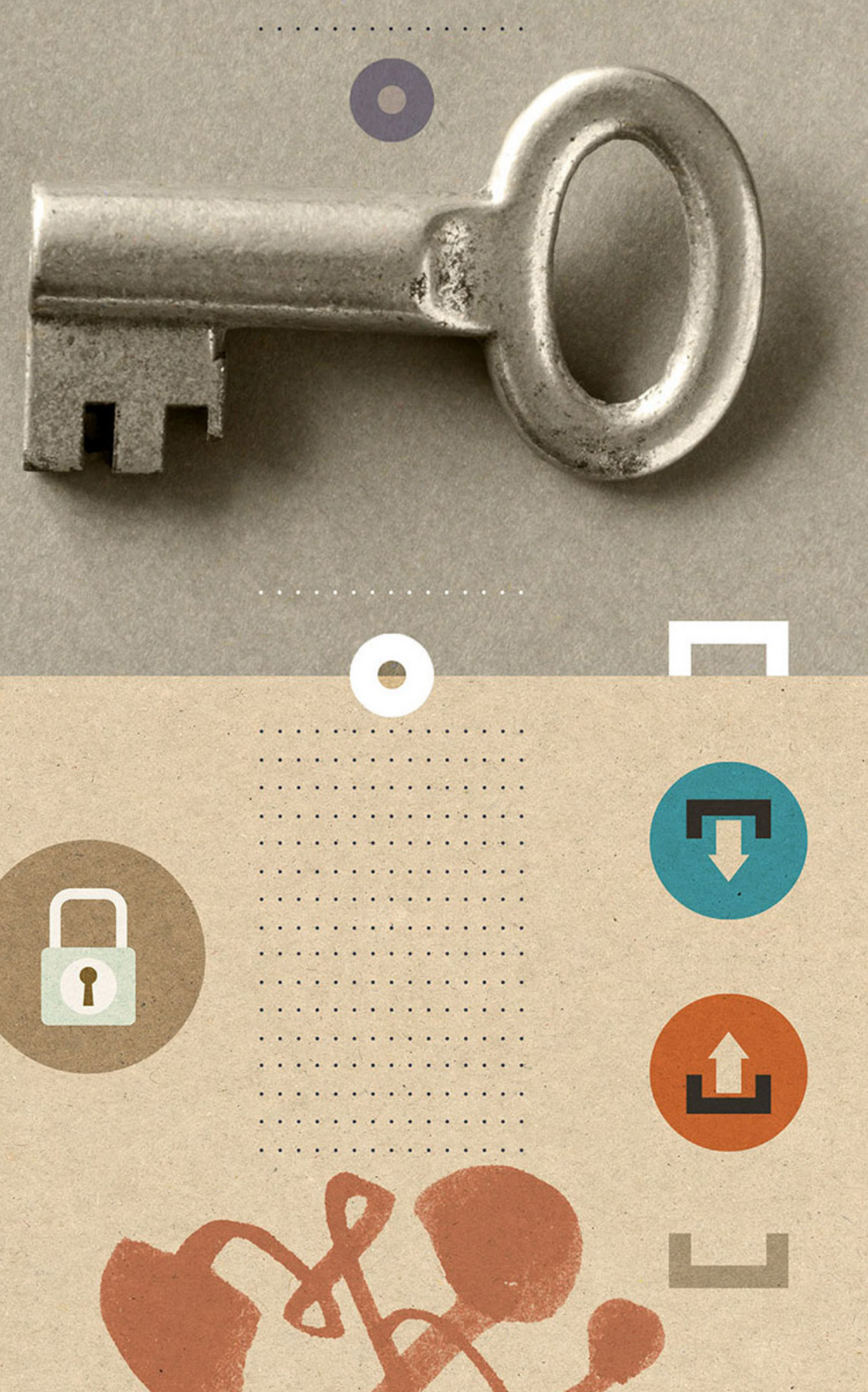




\title{
Direitos trabalhistas no Brasil: contendas teóricas sobre o significado da sua criação e do seu papel social
}

\author{
Labor Rights in Brazil: Theoretical \\ controversies on their creation and social role
}

\author{
Wallace Moraes* | Luciana Simas**
}

\begin{abstract}
Resumo
O artigo analisa as contendas teóricas acerca do significado da intervenção do Estado na criação dos direitos trabalhistas no Brasil. Tratamos de um problema específico: como parte da literatura das ciências sociais interpreta as leis do trabalho e o seu papel. Realizamos uma discussão bibliográfica, possibilitando-nos identificar os múltiplos princípios teóricos-metodológicos, explicitando suas características idiossincráticas. Identificamos postulados, metodologias e justificativas semelhantes que nos possibilitou enquadrá-las em diferentes correntes teóricas. Abordamos principalmente as escolas liberal, social-democrata e o populismo. Ademais, percebemos que grande parte da literatura trata a criação de leis trabalhistas como ações benevolentes dos governantes para o bem e para o mal. Essas conclusões retiram completamente a agência dos trabalhadores organizados. Com vistas a problematizar tais questões, nossa metodologia qualitativa privilegiou a acareação entre o diagnóstico das teses dos autores e o resgate de documentos históricos do período pré-1930. Como nossa contribuição ao debate, comprovamos a importância daação coletiva dos trabalhadores, por meio de suas ações diretas, para conquista de direitos, devolvendo a eles o protagonismo, normalmente preterido pelo "mainstream".
\end{abstract}

Palavras-chave: Direitos trabalhistas; social-democracia; liberalismo; ação direta, lutas dos trabalhadores.

\begin{abstract}
The article analyzes the theoretical disputes about the meaning of the State's intervention in the creation of labor rights in Brazil. We deal with a specific problem: as part of the social science literature it interprets labor laws and their role. We conducted a bibliographical discussion, allowing us to identify the multiple theoretical-methodological principles, explaining their idiosyncratic characteristics. We identified similar postulates, methodologies and justifications that allowed us to fit them in different theoretical currents. We mainly approach liberalism, social democracy and populism. In addition, we realize that much of the literaturetreats the creation of labor laws as benevolent actions by governments. These conclusions completely remove the agency from organized workers. In order to problematize such questions, our qualitative methodology privileged the confrontation between the diagnosis of the authors' theses and the rescue of historical documents from the pre-1930 period. As our contribution to the debate, from an alternative bibliography and historical documents, we prove the importance of the collective action of workers, through their direct actions, to conquer rights, giving them back the protagonism, normally overlooked by the "mainstream".
\end{abstract}

Keywords: Labor rights; social democracy; liberalism; direct action, workers' struggles.

\footnotetext{
* Professor associado do Departamento de Ciência Política e dos Programas de Pós-Graduação em Filosofia (PPGF) e História Comparada (PPGHC) da UFRJ. É pesquisador do INCT/PPED e líder do grupo de pesquisa OTAL/UFRJ. Realizou Pós-Doutorado na University of Florida e no INCT/PPED. Universidade Federal do Rio de Janeiro, Rio de Janeiro, RJ. Brasil. ORCID: 0000-0001-8179-468X. https://orcid.org/0000-0001-8179-468X. E-mail:moraesws@yahoo.com.br

** Escola Nacional de Saúde Pública (ENSP/Fiocruz). Doutora em Bioética, Ética Aplicada e Saúde Coletiva, IESC/ UFRJ, com intercâmbio na Universidade da Flórida - LevinCollegeof Law. Mestre em Direito e Sociologia (UFF); advogada com especialização em Direito Público. Integrante do Grupo de Pesquisa Saúde nas Prisões, da ENSP/Fiocruz; e do LIDHS (Laboratório Interdisciplinar em Direitos Humanos e Saúde) / UFRJ. Orcid: 0000-0003-2494-8747. E-mail: lucianasimas06@gmail.com
}

http://dx.doi.org/10.51861/ded.dmv.1.007 


\section{INTRODUÇÃO}

A regulação trabalhista é um dos temas mais visitados da literatura das ciências humanas no Brasil e várias de suas especialidades esforçaram-se para entender seus meandros. Destarte, a intervenção do Estado nessa regulação é vista sob diversos ângulos, cada qual com um conceito diferente. Assim, corporativismo (SCHMITTER, 1974; BOSCHI, 1978; DINIZ, 1978; COSTA, 1999; DELGADO, 2001); populismo (WEFFORT [1965], 1980; SAES, 2001; BOITO Jr., 2005; DREIFUSS, 1981); trabalhismo (FERREIRA, 2001; GOMES, 2001); relação legislada (CARDOSO, 2003; FRENCH, 2001); cidadania regulada (SANTOS, 1979; 1998); modernização conservadora (Moore, 1966; Domingues, 2002); clarividência das elites (FAORO, [1958] 2001); engenharia política proposta por pensadores positivistas (CARVALHO, 2001); modelo de capitalismo hierárquico (SCHNNEIDER, 2008), dentre outros, são categorias que tentam materializar, tanto a relação da compra e venda da força de trabalho, quanto a intervenção do Estado nesta.

As categorias supracitadas expressam as várias disputas interpretativas sobre o tema. Com efeito, buscaremos esclarecer um problema específico, a saber: como parte da literatura das ciências sociais compreende a criação de direitos trabalhistas no Brasil. Situaremos as leituras em matrizes teóricas, colaborando para entender como as análises são oriundas ou retroalimentam determinadas escolas. Nesse ínterim, mostraremos que os autores debatidos ao focarem diferentes ângulos chegam a conclusóes distintas.

Nossa metodologia qualitativa pautou-se em uma revisão bibliográfica, passando em revista fontes contemporâneas baseadas em alguns autores clássicos das ciências sociais. Apresentaremos suas teses e idiossincrasias teóricas, tendo como fio condutor suas posturas diante dos direitos trabalhistas. Essa exposição ocorrerá em forma de tópicos. Primeiro arrazoaremos os defensores originais da tese de outorga dos direitos trabalhistas. Depois, apresentaremos as questóes de alguns clássicos do pensamento social-democrata. No interior desse tópico, discutiremos as conclusóes de alguns autores que se autoproclamam trabalhistas. Logo a seguir, exporemos os postulados do pensamento liberal. Como penúltimo tópico, faremos uma discussão em torno do conceito de populismo e por fim apresentaremos nossas teses a partir de importantes fatos históricos ignorados por grande parte da literatura apresentada.

Destarte, o leitor terá tido acesso a um longo debate sobre a regulação trabalhista e seus significados. Decerto, no escopo desse artigo não seria possível tratar de todos os intelectuais que discutiram o papel das leis trabalhistas no Brasil. Privilegiamos assim alguns autores expoentes de determinadas 
escolas. Objetivamos perscrutar o quanto a luta do trabalhador para a conquista de direitosfoi importante para a criação das leis e ao mesmo tempo como esse fato foi propositalmente "esquecido" pela literatura aqui debatida em função dos princípios de suas matrizes teóricas.

Podemos destacar umacontenda central instigadora de conflitos interpretativos neste campo baseada na tese de Oliveira Viana (1951), segundo a qual"as leis trabalhistas foram concessões voluntárias do Estado para a classe trabalhadora, sem que a mesma exercesse qualquer pressão para sua criação”. Outra querela encontrada na literatura diz respeito aos papéis exercidos: a) pelo empresariado; b) pelos trabalhadores, na exigência e aceitação da CLT. Em comum, todos concordam que a chamada Revolução de 1930 foi um marco no desenvolvimento do capitalismo no país e alterou fundamentalmente a trajetória anterior. Por fim, mostraremos como a escolha de determinados conceitos para expressar uma opinião sobre o histórico da regulação trabalhista no Brasil demonstra uma filiação teórica.

É conveniente uma última ressalva antes da discussão bibliográfica. Nas décadas de 1930/40/50 predominaram análises autoritárias que defenderam o corporativismo estatal com centralização no papel do Estado. Entre 1960 e 1990, as análises marxistas, social-democratas, conservadoras e liberais disputaram a hegemonia nas ciências sociais, cada qual com seus postulados, métodos e conceitos. Os anos 1990 sobrepuseram as análises liberais e social-democratas, sobretudo pelo declínio da quantidade de interpretações marxistas e conservadoras. Os primeiros anos do século XXI, todavia, florescem novas interpretações. É nesta brecha que a nossa pesquisa busca se inserir, ampliando os horizontes de visão e contestação de diversas teses defendidas como verdades absolutas. Passemos ao debate.

\section{TESE DA DOAÇÃO DE DIREITOS TRABALHISTAS PELO ESTADO}

Como ponto de partida do debate bibliográfico, identificamos inicialmentea tese de outorga de direitos trabalhistas pelo Estado, defendida, tanto pelos principais ideólogos do Estado Novo (1937-45), como Oliveira Viana (1951), quanto pelo então presidente da República, Getúlio Vargas, e difundida amplamente pelo DIP (Departamento de Imprensa e Propaganda) de seu governo. Esta interpretação compóe a escola que podemos denominar por autoritária, cujo fulcro central assevera que a legislação trabalhista depois de 1930 foi "uma iniciativa do Estado, uma outorga generosa dos dirigentes políticos - e não uma conquista realizada pelas massas trabalhadoras" (VIANA, 1951). O Brasil podia afirmar com orgulho, insistia a propaganda estatal, que era um país "onde os operários conquistaram tudo sem 
um só ato de violência [e] sem ir às barricadas" (VIANA, 1951), por consequência de uma "concessão espontânea do Estado" (VIANA, 1951).

O discurso de Vargas, dirigido aos trabalhadores durante sua governança política, foi emblemático para entendermos as teses de outorga.

Tendes uma legislação que vos foi concedida sem nenhuma exigência, imposição ou pressão de qualquer ordem, mas espontaneamente. E isso é exatamente o que constitui o traço predominante que nos coloca, em matéria de legislação social, acima de todos os países. O que se chama de reivindicações trabalhistas não foram jamais obtidas em qualquer país, como estão sendo aqui verificadas. No Brasil, não há reivindicaçôes nesse assunto. Há concessões. Concessões do governo aos eficientes colaboradores, que são os trabalhadores, quer braçal, quer intelectual (CARONE, 1974: 227, in BOITO, 2005: 24).

Estas afirmaçốes foram amplamente repetidas pelopaís e muitos teóricos acabaram por reproduzi-la acriticamente, de modo que, ainda hoje, essa conjectura persiste com grande força.

O segundoargumento, defendido pelos intelectuais orgânicos do governo Vargas, sustenta-se na ideia, segundo a qual as leis trabalhistas e sindicais eliminaram o espírito antipatronal, "suprimiram resolutamente a agitação daninha, e criaram uma elite colaboradora na classe operária” (VIANA, 1951). Assim, o Estado brasileiro teria garantido a ordem social capitalista, desviando os trabalhadores dos ideais comunistas/anarquistas. Tudo isso ocorreu com o apoio do patronato (VIANA, 1951). Percebamos que a ideia de corporativismo estatal e, portanto, autoritária ocupa o protagonismo da perspectiva teórica de Viana e consequentemente do varguismo em geral. É mister registrar que a classificação corporativista assume duas posições díspares. Se for enquadrada como societal, trata-se de modelo em que trabalhadores, patróes e Estado, autonomamente, fazem uma concertação livremente negociada. Quando classificada em corporativismo estatal, significa que o Estado dita as normas para os demais autoritariamente.

Começar com o discurso de Vargas e os argumentos de Viana (1951) é importante, pois toda a discussão que segue, diretamente ou não, debaterá com os mesmos. Com efeito, perpassaremos por essa construção teórica durante a exposição das diferentes interpretações e concluiremos voltando à mesma.

\section{CARACTERISTTICAS DAS INTERPRETAÇÕES SOCIAL- DEMOCRATA}

A interpretação social-democrata é institucionalista e abarca o maior número de pesquisas com utilização de grande quantidade de conceitos, a 
saber: nacional-desenvolvimentismo, cidadania regulada, trabalhismo, conjuntura crítica e outras. Todas as suas leituras têm em comum a exaltação da participação do Estado na regulação trabalhista com a intenção prioritária de defender o trabalhador, que nessa interpretação seria presumidamente hipossuficiente.Essa corrente ao mesmo tempoem que defende direitos aos governados, não contesta os pilares do capitalismo. Por consequência, o modelo interpretativo social-democrata no Brasil se mostrou como um tributário extraviado das ideias de Karl Marx por normalmente não valorizar a luta de classes e o papel histórico do proletariado para a conformação trabalhista, conquanto defenda que o trabalhador tenha direitos. Assim, se posicionou entre o marxismo, na defesa da igualdade social, e o liberalismo, ao não desferir uma profunda crítica ao sistema dominado pelo dinheiro.Este modelo interpretativo, ao longo da história republicana brasileira, quando não foi hegemônico, foi um dos mais utilizados. No novo milênio, ele tem se mostrado bastante presente. Entendamos melhor.

Ao descrever o histórico da cidadania no Brasil, com a consequente implantação de direitos trabalhistas, José Murilo de Carvalho (2001) advoga que os direitos sociais foram criação política de pensadores positivistas, não tendo os trabalhadores nenhuma participação. Seus argumentos amparam-se nas seguintes premissas:

A proteção do Estado ao trabalhador sindicalizado modificava a situação de confronto direto existente anteriormente e aumentava o poder relativo dos operários[...] os trabalhadores foram incorporados à sociedade por virtude das leis sociais e não de sua ação sindical e política independente (CARVALHO, 2001: 117 e 124).

Deste modo, aproxima-se das teses corporativistas estatais de Viana (1951) e Vargas que veem o Estado como doador espontâneo de direitos.

Ademais, o autor enfatiza que os direitos trabalhistas foram criados justamente em duas ditaduras: a de Vargas (1937-45) e a dos militares (1964-85). $\mathrm{Na}$ primeira, disse ele, instituíram-se direitos para os trabalhadores urbanos; na segunda, para os rurais. Como o autor não complexifica, nem contextualiza suas assertivas, abre-se uma brecha, por inferência simples, para se pensar no papel benevolente e generoso dos ditadores para com os governados.

Percebamos que as premissas de Carvalho (2001: 124) são as mesmas de Viana (1951), pois incorporam a tese do Estado protetor do trabalhador como princípio condutor de seu exame; além disso, o controle do Estado sobre o sindicato também é visto como benéfico para o proletariado.

O coroamento das conjecturas de Carvalho sobre a criação dos direitos trabalhistas no Brasil emerge quando afirma que eles surgiram por influência das ideias positivistas de Auguste Comte, as quais pregavam a cooperação 
entre trabalhadores e patrões na busca de soluções pacíficas para os conflitos. De acordo com o intelectual, os positivistas tentaram impor uma legislação social já no início da República em 1889. Não conseguiram. Mas com a revolução de 1930, chegando ao poder políticos do Rio Grande do Sul, estado brasileiro com maior influência do positivismo, finalmente os direitos sociais puderam ser postos em prática (Carvalho, 2001). Vejamos.

A maior influência do positivismo ortodoxo no Brasil verificou-se no estado do Rio Grande do Sul. (...) o fato de o chefe da revolução de 1930, Getúlio Vargas, e seu primeiro ministro do Trabalho, Lindolfo Collor, serem riograndenses ajuda a explicar a ênfase que passou a ser dada à questão social (Carvalho, 2001: 111).

Como parte da mesma escola de Carvalho, está a análise de Raymundo Faoro [1958] (2001) com forte amparo na história política - as questóes sociais são secundarizadas em relação àquela. $\mathrm{O}$ autor busca convencer que a legislação trabalhista fora prometida por Getúlio Vargas e a Aliança Liberal na campanha eleitoral de 1930. Além disso, seguindo uma metodologia weberiana, separa o público e o privado, insistindo em identificar a facilidade com que os empresários tinham acesso aos recursos públicos. Isto posto, cita um discurso de Vargas, no qual podemos perceber suas promessas de campanha mais tarde cumpridas:

Se nosso protecionismo favorece os industriais, em proveito da fortuna privada, corre-nos, também, o dever de acudir ao proletariado, com medidas que the assegurem relativo conforto e estabilidade e o amparem nas doenças como na velhice" (FAORO, 2001: 773).

Vejamos como a criação de instituições trabalhistas aparece descolada da pressão dos trabalhadores, no trecho de Faoro (2001: 806/07):

O primeiro passo desta jornada será a disciplina social e jurídica do proletariado, com a fixação de seus direitos e seu capitaneamento governamental. As reivindicações operárias, antes de 1930, não conseguiram, apesar de leis votadas e não aplicadas, conquistar posição de barganha na sociedade, nem reconhecimento oficial. Perdidas entre o anarquismo e o comunismo, sofriam hostilidade dos grupos dominantes, que as encaravam como ameaças à ordem pública. (...) No poder cria o Ministério do Trabalho (...) com a política conciliatória de classes, em repúdio implícito à linha contestatória dos frágeis movimentos operários anteriores.

No fundo, a interpretação de Faoro (2001: 791) fundamenta-se na ideia de que Vargas evitaria o comunismo, conciliando o operariado e o empresariado, e se afastaria do fascismo, oficializando os grupos de pressão capitalistas. Simultaneamente, está claro na glosa de Faoro sua percepção negativa com relação às ideias anarquistas e comunistas, que não favoreciam os 
interesses dos trabalhadores. Em vista disso, Faoro também converge com as teses de direitos trabalhistas doados pelo Estado.

Outra chave de leitura foi produzida por Wanderley Guilherme dos Santos $(1998)^{1}$, que historia a regulação trabalhista no Brasil a partir do exame puro e simples da leitura da lei. Seu trabalho tem grande valor, pois descreve paulatinamente como foi construído todo o arcabouço legal trabalhista e previdenciário no Brasil. Neste sentido, ele percorre desde o século XIX até o advento dos direitos sociais no país, verificando o teor liberal das Constituiçốes de 1824 e 1891, que não preconizavam regulamentação sobre compra e venda da força de trabalho, bem como as intervençóes corporativistas a partir de 1930. Para tanto, cunhou a expressão cidadania regulada, significando um sistema de estratificação ocupacional definido por norma legal, cujos cidadãos são aqueles membros da comunidade, que se encontram localizados em qualquer uma das ocupações reconhecidas e definidas em lei. A partir desta percepção, caracteriza-se como pré-cidadãos todos cuja ocupação não for reconhecida legalmente. O conceito foi bastante eficaz.

De acordo com a interpretação de Santos (1998:71), as primeiras regulamentações sociais no Brasil ocorreram antes da República, em 1888, e foram destinadas aos funcionários públicos. A partir dessa premissa, o autor cita lei por lei, começando pela Lei 3.397, de 24 de novembro de 1888, que amparou os empregados das estradas de ferro sob a forma tradicional de Caixa de Socorro,provendo pequena ajuda durante período de doença e auxílio funeral, seguida pelo Fundo de Pensóes do Pessoal das Oficinas da Imprensa Nacional e outras.

Com o advento da República, a trajetória iniciada no fim do Império não foi revertida; ao contrário, foi intensificada. De acordo com a maneira de ler as leis segundo Santos (1998), elas continuaram sendo implementadas para os trabalhadores públicos de setores estratégicos do Estado. Assim diz ele:

Desta forma, o processo tende a se disseminar por estratos cada vez mais amplos da sociedade e cobrindo incidentes cada vez mais diversos. De modo que a primeira lei de férias, de 15 dias, segue para os trabalhadores no abastecimento de água da capital federal, em 1889, logo estendida aos ferroviários da estrada de ferro Central do Brasil. Até 1912 os trabalhadores do Ministério da Fazenda, do arsenal da Marinha do Rio de Janeiro, da casa da moeda e do porto do Rio de Janeiro foram beneficiados com parcos direitos sociais, mas constituíam classes privilegiadas em um contexto de absoluta negação de direitos para os trabalhadores em geral. Em 1926, já existiam 33 caixas de aposentadorias e pensóes. (Santos, 1998:71). 
Mesmo quando Santos trata da iniquidade das leis em prol dos trabalhadores, ela aparece descolada de qualquer luta, aparentando uma iniciativa generosa de determinados parlamentares. Vejamos:

[...] foram inócuos os projetos legislativos de regular o mercado de trabalho no setor privado. O trabalho infantil nas fábricas foi regulamentado em 1890, mas foi descaradamente desobedecido. Em 1911, tentou-se regular a jornada de trabalho em 12 horas, impedir o trabalho aos domingos e feriados, proibir o trabalho noturno de menores de 18 anos e dos menores de 10 anos mesmo durante o dia. Estes projetos de lei foram todos arquivados e rejeitados pelos parlamentares, executivos e empresários. (Santos, 1998:72)

Adalberto Moreira Cardoso (2003) traz novas questôes para o debate. Analisa a regulação trabalhista, privilegiando suas mudanças legislativas, tal como fizeram Vianna (1976), Santos (1979) e Gomes (1979), não obstante, privilegia as contendas entre patrôes e empregados na Justiça do Trabalho, publicando sobre o assunto várias pesquisas significativas (2006; 2007).

Cardoso é um defensor da intervenção do Estado na regulação trabalhista, portanto, distancia-se da corrente liberal e se enquadra no que chamamos de articulação social-democrata, com uma clara concordância com Polanyi (2000):

apenas aqui não se reconheceu que o mercado, deixado a si mesmo, o mercado sem o Estado, é a guerra (...). É esse, parece-me, o risco maior da flexibilização e da desregulamentação do mercado de trabalho tal como propostas pelos vencedores da guerra ideológica na década neoliberal (CARDOSO, 2003).

Sem embargo, outra eminente questão trazida por Cardoso (2003) foi o entendimento da regulação estatal das relações de trabalho como um modelo típico legislado, tal como o francês. Assim, o conceito de corporativismo não serviria para explicar a CLT (Consolidação das Leis Trabalhistas), mas apenas a legislação sindical, inspirada na Carta Del Lavoro de Mussolini. De acordo com o autor, a categoria remeteria a regimes de negociação de interesses entre capital, trabalho e Estado em mecanismos tripartites relativamente autônomos de produção de regras; ou ao modelo fascista (CARDOSO, 2003:90). Logo, descarta classificar o modelo brasileiro tanto como corporativismo societal, quanto estatal.

A partir de uma percepção positiva da legislação trabalhista brasileira, materializada no período Vargas, Cardoso (2003) a classifica como relação legislada a partir dos critérios abaixo.

"O direito do trabalho recobre, ou regula, dois tipos de relações:

1. as relaçôes de trabalho propriamente ditas, isto é, aquelas entre patróes e cada um de seus empregados, pelas quais se troca trabalho 
por remuneração, se definem as regras de acesso ao emprego (idade mínima e máxima, por exemplo), o lugar em que o indivíduo ocupará no organograma da empresa, e regras mais universais como a que regula a jornada de trabalho etc.

2. as relaçóes profissionais, por meio de regras para a defesa e representação de interesses das partes, capital e trabalho. São as relaçóes de direito coletivo e recobrem a organização sindical, a ação coletiva, a negociação coletiva, a representação por locais de trabalho etc.”

Cardoso retirou o foco na maneira como a legislação brasileira foi produzida, sem a participação dos trabalhadores, e jogou luz sobre o que preconiza a lei, que define direitos aos governados. Mudando o foco, pode caracterizar a legislação como positiva, negligenciando o amplo controle do Estado sobre os trabalhadores organizados limitando sua liberdade. Voltaremos a esse ponto na conclusão.

\section{Características das interpretações a partir do conceito de trabalhismo}

A interpretação a partir do conceito de trabalhismo assume uma postura absolutamente crítica ao uso da categoria populismo e, por conseguinte, idolatra o período Vargas. Esta interpretação é compartilhada por vários intelectuais brasileiros. Nossa exposição está baseada principalmente nos textos de Ferreira (2001) e Gomes (2001), cujas teses se encontram na introdução da obra "O populismo e sua história":"O trabalhismo orientou-se por um eixo, por uma estrutura dorsal nacionalista, distributivista e desenvolvimentista, permitindo a constituição de um projeto para o país, marcado por forte solidariedade social” (FERREIRA, 2001: 14/15).

$\mathrm{Na}$ defesa desta perspectiva, Ferreira busca por todas as maneiras ridicularizar a ideia transmitida pelos autores que utilizam a terminologia "populismo", segundo a qual as massas de trabalhadores eram controladas de todos as formas, inclusive, em seus pensamentos.

Ao tentar desmistificar o conceito de populismo, Ferreira (2001: 62/63) efetivamente opõe duas posiçóes acerca do papel do Estado. Uma que o concebe como um ator que possa ter funções benéficas para a sociedade em geral e para os trabalhadores, em particular, como no caso da criação de direitos sociais. A outra que concebe o Estado como um ator defensor dos interesses das classes dominantes. Esse é o principal mote, não dito, da polêmica entre populismo e trabalhismo.Enquanto aquele segue uma linha claramente marxista, a segunda ampara-se na social-democracia. Ferreira defende a primeira proposição, por isso é um social-democrata, ou trabalhista, como ele se auto-define. 
Quanto ao pensamento de Angela de Castro Gomes, cabe fazer uma ressalva. Ao analisarmos trabalhos de diferentes períodos dessa autora (1979 e 2001), percebemos uma considerável tergiversação. No primeiro, há uma forte utilização da história e consequentemente o privilégio das lutas sociais, principalmente anarquistas da década de 1910 no Brasil. Neste sentido, suas conclusóes mostram que o governo Vargas assumiu uma postura pressionada pela classe trabalhadora. Já no seu último trabalho, redireciona o papel ativo dos trabalhadores que conscientemente teriam apoiado o governo.

De todo modo, Gomes critica o conceito de populismo por trazer:

as ideias de uma classe trabalhadora 'passiva' e sem consciência, sendo 'manipulada' por políticos inescrupulosos que a 'enganavam', e que não tinham, na verdade, representatividade política e social. O que eu pretendia demarcar era justamente que não aceitava esta concepção, nem de classe trabalhadora, nem de pacto político" (Gomes, 2001: 55).

A partir da percepção de Gomes (2001), podemos inferir duas questôes: 1) os trabalhadores não foram manipulados pelos governantes; 2) suas açôes foram conscientes e ativas. Por fim, esta interpretação leva-nos a outro extremo da visão a partir do populismo: valorização exacerbada dos governantes do período de 1930 a 1964, como produto de variáveis deveras favoráveis ao trabalhador.

\section{CARACTERÍSTICAS DAS INTERPRETAÇÕES LIBERAIS SOBRE OS DIREITOS TRABALHISTAS}

Sob a denominação que pode ser enquadrada como genuinamente liberal, estão as análises de Simone Saísse (2005) e José Pastore (1997) - legítimos representantes do capital industrial no país ${ }^{2}$ - e John French (2001) e Ben Schneider (2008) - brasilianistas estadunidenses.

O primeiro passo para a melhor compreensão desta vertente é caracterizar os postulados do liberalismo que sustentam suas interpretaçóes. Já podemos adiantar que todas elas, de diferentes maneiras, criticam a regulação estatal como excessiva e prejudicial ao desenvolvimento das empresas e do país, por consequência leem como maléficas também ao trabalhador. Trata-se da velha máxima liberal, segundo a qual o Estado não deve intervir na economia, mantendo uma postura de baixa regulação jurídica. A primazia do contrato individual entre as partes, ou seja, do negociado sobre o legislado, é o que propóem como ideal para a relação empregador-trabalhador.

Uma das principais características da interpretação liberal é focar na qualidade do ambiente para o mundo dos negócios e o desenvolvimento do capitalismo, privilegiando estudos sobre os ganhos do mercado e as condiçóes 
para crescimento econômico. Assim, normalmente, ignora tanto a organização quanto as reivindicaçôes dos trabalhadores, que serviriam como obstáculos para o acúmulo de capital.

As supracitadas premissas ajudam a explicar o porquê destas leituras adotarem, acriticamente, o discurso dos defensores do Varguismo, segundo os quais não existia movimento operário antes de 1930 e que o mesmo foi impulsionado equivocadamente por Vargas. A grande diferença é que os liberais veem o suposto supracitado impulso como um movimento equivocado do varguismo. Simultaneamente, criticam a criação de direitos que teria "travado o desenvolvimento da economia."

Por consequência, para Schneider e French (2001: 91-93), o Estado fraco promoveu o fortalecimento do movimento operário na tentativa de formar uma base social para vencer as oligarquias adversárias e os industriais paulistas.

Esta interpretação apresenta o Estado com interesses próprios e absolutamente descolados das postulações dos governantes da economia (empresários). Em outras palavras, defendem que os direitos sociais foram construídos pela engenharia de Vargas, buscando favorecer seus próprios interesses em detrimento das elites da época.

Schneider (2004b:38) surpreende quando afirma que os governantes políticos brasileiros nunca estenderam benefícios seletivos para as associações empresariais, como acesso privilegiado ou funções públicas. Conclui que o Brasil tem as associações de classe dos negócios mais fracas da América Latina. Novamente, do ponto de vista histórico, sua análise ignorou os anéis burocráticos durante os governos militares como acesso privilegiado dos empresários aos burocratas estatais (CARDOSO, 1974). Ignorou, ainda, os representantes em Ministérios, desde Mario Henrique Simonsen até Paulo Guedes ${ }^{3}$.

French (2001) argumenta que havia uma incongruência entre lei trabalhista e realidade no Brasil. Sob essa perspectiva, o foco central estava no excesso de leis, não no fato delas não serem respeitadas pelos governantes da economia, nem, convenientemente, fiscalizadas pelo Estado. O brasilianista argumenta que a economia não podia suportar as leis de bem-estar: "tais leis trabalhistas desaceleravam o crescimento econômico e efetivamente subvertiam a base lógica para a organização sindical” (FRENCH, 2001: 28). Todavia, o forte controle do Estado, através de explícita coerção, sobre os trabalhadores rebeldes não foi lembrado pelo intelectual.

Uma lacuna importante que o autor não leva em consideração é que a economia brasileira foi uma das que mais cresceu no mundo, desde a criação das leis trabalhistas. Portanto, não podem ser apontadas como empecilho 
para o crescimento. Apesar de basear-se, em parte, em fontes muito perigosas, conversas informais, o autor salienta um importante aspecto, a saber: as leis trabalhistas não eram respeitadas no país. Nada difícil de acreditar tendo em vista que ainda hoje muitas delas seguem não sendo aplicadas. ${ }^{4}$

A legalização do movimento sindical, segundo French (2001), favoreceu a organização dos trabalhadores. $\mathrm{O}$ forte controle do Estado sobre o movimento sindicalista não foi problematizado pelo autor. Por fim, o brasilianista (2001: 89) alega que os empregadores industriais se opuseram e resistiram renitentemente a quase toda espécie de iniciativa previdenciária, trabalhista e regulatória do Estado.

Sob o mesmo foco liberal, crítico da legislação trabalhista, Saísse (2005) e Pastore (1997) defendem a flexibilização de direitos com vistas a favorecer aos trabalhadores. Esta argumentação pauta-se na ideia de que retirando direitos dos governados seria melhor para todos, pois aumentaria a oferta de empregos e os salários subiriam.

A partir do exposto percebemos que a literatura liberal coloca em lados antagônicos direitos trabalhistas versus condiçôes de acumulação de capital e de desenvolvimento econômico, estando preocupada em defender estas. Sob essa perspectiva, os direitos trabalhistas apresentam-se como perdulários e obstáculos para a mais ampla competição individualista.

\section{O CONCEITO DE POPULISMO}

Um dos conceitos mais largamente utilizados para tratar o período de 1930 a 1964 foi o de populismo. Podemos destacar as análises de Saes (2001), Boito (2005) e Dreifuss (1981) como parte desta grande literatura. Não obstante, seu texto clássico impulsionador foi o de Weffort [1965] (1980). De acordo com sua visão, o populismo caracterizar-se-ia por governos sempre sensíveis às pressôes populares; ao mesmo tempo, recebiam seu apoio e as manipulavam. Na prática, representava a "ascensão das massas" na política brasileira, corolário do desenvolvimento urbano e industrial.

A interpretação a partir da categoria populismo significa entender o período como uma pura contradição. Por um lado, concebia os mecanismos "através dos quais as classes dominantes exerciam sua dominação"(Weffort, 1980); e, por outro, também resumia o quanto esse domínio se viu ameaçado pela emergência dos governados enquanto classe organizada.

Trata-se de uma interpretação clássica do marxismo no Brasil. Nesse sentido, dão grande valor ao papel das classes sociais, através da sua constante luta e, mormente, verificam o papel dos industriais, das classes médias, das oligarquias e das massas de trabalhadores, divididos em rurais e urbanos, 
cujos interesses seriam diferentes. Com efeito, segundo Boito (2005: 24/30), o populismo teve origem no seio da baixa classe média e da pequena burguesia, podendo ser caracterizado como um estatismo reformista.

Portanto, a criação dos direitos trabalhistas, de acordo com esta interpretação, foi decorrência das ações dos governantes com vistas a manipular os governados para seus interesses eleitorais, num contexto de emergência das massas. Isso ajuda a entender porque na década de 1940 os ideólogos governamentais fizeram questão de dizer que a criação de direitos foi uma atitude espontânea e generosa dos governantes.

O conceito de populismo pelo veio marxista - portanto diferente das interpretações liberais, social-democratas e autoritárias - situa a criação de direitos do trabalho num contexto de emergência das massas, mas ainda realizado pelos governantes como um ato de estratégia eleitoral. Mostraremos que foi mais do que isso.

Cabe frisar que na atual conjuntura todos os políticos que direcionam políticas públicas para as camadas mais pobres são taxados pela grande mídia e seus doxósofos de populistas, principalmente se retiram recursos das camadas abastardas. Assim, sua larga utilização nos induz a uma perspectiva equivocada com relação à origem do conceito. Não porque ele descreve erradamente os acontecimentos do período, mas porque foi apropriado por um discurso despolitizador de fundo plutocrático, que critica todas as açóes do Estado em prol dos pobres.

\section{O RESGATE DA CONTRIBUIÇÃO DOS TRABALHADORES}

O jurista Evaristo de Moraes Filho [1952] (1978) foi um dos primeiros a combater a ideia de doação das leis trabalhistas pela governança política de Vargas. Segundo ele, não houve outorga nenhuma. As massas operárias lutaram durante um triênio pelo advento de leis que lhes melhorassem as condiçôes de vida. Houve greves, lutas, sangue, desespero, prisóes, mortes (Moraes Filho, 1978).

Moraes Filho depois de descrever o testemunho de seu pai junto com o manifesto dos trabalhadores de 1906, conclui:

vê-se bem o quanto há de falso o pretender-se fazer da classe operária o espectador inerme dos fatos que lhe diziam respeito, sem a menor parcela de iniciativa e de luta em prol de uma legislação protetora. Constitui, igualmente, outra afirmativa sem fundamento a declaração de que estes movimentos nunca pressionaram o governo e as classes patronais (Moraes Filho, 1978: 192).

Sob foco analítico similar, encontra-se a pesquisa de Luiz Werneck Vianna [1976] (1999). Ele combate a premissa dos direitos sociais como dádiva do 
Estado e descreve o importante papel desempenhado pela classe trabalhadora nas décadas precedentes. Do mesmo modo, aborda o abandono das teses liberais por parte do empresariado e a aceitação da garantia de direitos como benéfica, inclusive para seus lucros. Vianna ainda faz questão de frisar que boa parte das leis trabalhistas já estava pronta antes de 1930. Nesse sentido, combate a tese de outorga do Estado, de Oliveira Viana, mas concorda com o mesmo sobre os benefícios trazidos pelas leis trabalhistas e sindicais para o empresariado.

Em função disto, Werneck Vianna (1999) desmistifica algumas ideias acerca da Era Vargas e seu suposto favorecimento aos trabalhadores. A primeira diz respeito ao caráter de dádiva por parte do Estado independentemente de pressão exercida de baixo por boa parte dos operários. A segunda, decorrente desta, concebia a revolução de 1930 como um marco divisor, quando a partir de então a chamada "questão social" teria deixado de se constituir num "caso de polícia”, passando o Estado a disciplinar o mercado de trabalho em benefício dos assalariados.

De acordo com Vianna (1999), a consolidação de uma legislação trabalhista no Brasil é fruto dos acontecimentos de 1935, com a conhecida "Intentona comunista” e a pressão da Aliança Nacional Libertadora.

As análises de Vianna (1999) e Moraes Filho (1978) são fundamentais no propósito de resgate da importância do papel da luta dos trabalhadores para a criação de direitos. Não obstante, é necessário ir um pouco mais longe na História e constatar que a criação de direitos trabalhistas, por sua vez, é resultado de um acúmulo de lutas desde as greves gerais do final da década de 1910. Elas fizeram com que as elites e o Estado pensassem em abandonar o liberalismo e criar direitos trabalhistas sob viés corporativista. Um pacto que não foi organizado com a participação dos trabalhadores, ficando restrito aos governantes políticos e econômicos, que decidiram os rumos dos direitos sociais e do ordenamento jurídico que lhes regula, mas atendeu algumas demandas históricas dos governados.

A luta foi um fator tão importante que ajuda a compreender o fato de os direitos serem exclusivos para o setor mais combativo dos trabalhadores na época, o operariado urbano. Aos trabalhadores do campo, menos organizados naquele período, e sob controle dos “coronéis”, não lhes foram previstos direitos.

Os arsenalistas, por exemplo, deflagraram greves e fundaram a União Operária, bem como publicaram o jornal O Niilista, já em 1880 (RODRIGUES, 2004: 34). Podemos dizer o mesmo dos portuários, dos ferroviários e dos trabalhadores no abastecimento de água da capital federal. Faoro (2001:756) nos dá o tom da importância da classe trabalhadora neste contexto: 


\begin{abstract}
Diversas greves e movimentos reivindicatórios agitam o meio operário, desde a primeira hora republicana, com o tenente Vinhais na liderança dos ferroviários, na capital da República. Vez ou outra irrompe uma greve local, de proporçôes reduzidas e diminutas, até que, a partir de 1917, elas atingem grau de efervescência revolucionária. Nesse momento - 1917-19 - a classe média urbana manifestou simpatia pelos movimentos [...]".
\end{abstract}

Com efeito, o governo de Arthur Bernardes criou o Conselho Nacional do Trabalho, Caixa de Pensóes dos ferroviários e institui o feriado nacional a 1o de Maio. A lei de férias foi legislada em seu governo, depois de contundente pressão dos governados. De 1902 a 1909, houve uma sequência de greves, sucessivamente, protagonizadas por portuários, estivadores e ferroviários (Samis, 2004:154). Não obstante, é bom lembrar que essas não foram as primeiras greves no Brasil, pois trabalhadores escravizados já haviam realizado movimentos equivalentes anteriormente (GOMES \& NEGRO, 2013).

$\mathrm{Na}$ mesma linha argumentativa, mas sob o prisma da sociologia econômica, Francisco de Oliveira (2003) entende que as leis trabalhistas fizeram parte de um conjunto de atitudes destinadas a instaurar um novo modelo de acumulação. A população que afluía às cidades era importante para a conversão de enormes contingentes populacionais em 'exército de reserva', questão fundamental à reprodução do capital. Neste sentido, a legislação trabalhista igualava reduzindo - antes que incrementando - o preço da mão-de-obra (OLIVEIRA, 2003: 38). O resultado desse processo foi impedir a formação precoce de um mercado dual de força de trabalho que poderia pôr em risco a viabilidade da empresa nascente (OLIVEIRA, 2003: 38). Por fim, afiança Oliveira:

se o salário fosse determinado por qualquer espécie de 'mercado livre', na acepção da teoria da concorrência perfeita, é provável que ele subisse para algumas categorias operárias especializadas; a regulamentação das leis do trabalho operou a reconversão de um denominador comum de todas as categorias, com o que, antes de prejudicar a acumulação, beneficiou-a. (Oliveira, 2003: 39).

Em perspectiva absolutamente contrária à liberal, Oliveira lê a intervenção do Estado na regulação trabalhista como benéfica ao grande capital que teve o preço da mão-de-obra rebaixado, além, é claro, da contenção das reivindicações trabalhistas.

Segundo Samis (2004), as primeiras greves no Brasil datam de janeiro de 1858. Entretanto, diz o autor, foi no início da República que as reivindicações operárias ganharam uma expressão nunca verificada. No final do século XIX, a jornada de trabalho diária oscilava entre 10 e 16 horas e aos domingos ia até ao meio-dia. Os filhos dos operários, de cinco a oito anos, trabalhavam nas fábricas para ajudar no sustento da família (RODRIGUES, 
2004: 29). Nesse período foram criadas entidades organizativas dos trabalhadores, como o Centro Operário Radical e o Centro das Classes Operárias. No início do século XX, em 1903, surgiu a Federação das Associações de Classe no Estado do Rio de Janeiro, seguindo o modelo da CGT francesa. Em São Paulo, no ano de 1905, os sapateiros, padeiros, marceneiros e chapeleiros fundaram a Federação Operária de São Paulo (FOSP) e, no primeiro ano do Congresso Operário, no Rio de Janeiro, foi criada a Federação Operária do Rio de Janeiro (FORJ) (SAMIS, 2004: 134). Com efeito, o sindicalismo revolucionário tinha se tornado hegemônico no movimento operário (FARINHA NETO, 2007: 13).

$\mathrm{Na}$ primeira década do século XX, por todo o país foram deflagrados 111 movimentos grevistas, na sua maioria por questóes salariais. Durante a conjuntura dos anos de 1917-1919, somente no eixo Rio-São Paulo, outras mais de duzentas podem ser acrescidas ao número verificado até 1910 . As reivindicaçóes eram das mais diversas. De acordo com Rodrigues (2004: 30), os trabalhadores impunham a seguinte pauta - é importante lê-la para saber, não só as más condiçôes em que viviam os trabalhadores, quanto os abusos dos patrôes:

[...] exigiram a redução da jornada de trabalho até alcançar as oito horas com descanso semanal aos domingos; o seguro obrigatório de acidentes de trabalho; um tratamento mais humano e mais justo da parte dos patróes e das autoridades; pleitearam melhores condiçốes de higiene; bateram-se pela obrigatoriedade do pagamento dos salários em dia certo e em dinheiro (grande parte dos patróes pagavam com vales para ser trocados por alimentos em seus armazéns, a preços mais caros do que nas outras lojas); reivindicavam o direito e a liberdade de reunião e associação, tantas vezes burlados pelas autoridades; lutaram por um lugar digno dentro da sociedade; combateram publicamente os aumentos do custo de vida, dos aluguéis; as guerras, e o serviço militar obrigatório.

A greve geral de 1917, por exemplo, resultou em algumas conquistas para a classe operária paulistana, como a implantação, em determinadas fábricas, da jornada de 8 horas e aumentos salariais (SAMIS, 2004: 142). Na Capital Federal, a aglomeração presente ao evento contou com cerca de $60 \mathrm{mil}$ pessoas. A solidariedade entre os governados era outra marca desta época. Rodrigues (2004: 31) relata a ajuda dos sapateiros aos tecelóes em greve. Para vencer a resistência dos patróes, cada sapateiro assumiu o compromisso de tomar conta de um filho de um tecelão e sustentá-lo em sua casa até a vitória. Outra característica foi a grande quantidade de jornais combativos: A Plebe, Voz do Povo, Vanguarda Operária, A Hora Social, La Bataglia, O Amigo do Povo, A Terra Livre, A Voz do Trabalhador e outros. As supracitadas greves arrancaram dos governantes da economia a jornada de oito horas, a semana 
de seis dias e a igualdade de salários entre homens e mulheres (SAMIS, 2004: 145). Foi a União dos Operários em Construção Civil (UOCC) que garantiu, pela primeira vez, em maio de 1919, para toda a categoria, o benefício definitivo da jornada de 8 horas (SAMIS, 2004: 146).

Com efeito, foram as greves gerais de $1917 / 18 / 19$ as responsáveis pela mudança de postura do patronato, fazendo-o deixar de se opor, por princípio, à intervenção do Estado, no que diz respeito à implementação da legislação social no país (Vianna, 1999; Addor, 2002; e Gomes, 1979). Gomes (1979: 36) chama a atenção para o fato de os benefícios da implementação das políticas sociais atingirem primeiramente o operariado urbano, pois este setor constituía uma ameaça política maior à ordem, e a decisão de a quem se deveria incluir ou excluir levava em conta justamente este tipo de consideração.

Neste aspecto, a mudança de posição dos empresários impunha-se não no sentido de reconhecer a necessidade de se atentar para a justiça social per se, mas com o objetivo de prevenir e/ou impedir "perturbaçôes” da ordem pública e, principalmente, prejuízos e/ou diminuição de seus lucros. Apenas em 1917, depois das primeiras greves operárias, foi criada a Comissão de Legislação Social na Câmara dos Deputados, que ganhou competência em 1926 para regular as relações trabalhistas.

Para ilustrar nossa análise, comentamos, a seguir, três reportagens publicadas em jornais de época que explicam mais do que muitas teorias.

O jornal O Estado de S. Paulo, de 21 de dezembro de 1923, descreveu os casos de insubordinação do operariado. Vejamos este valioso documento publicado em Carone (1977: 386-389).

A história das indústrias da cidade de Sorocaba está intimamente ligada ao nome do delegado da polícia da região - sr. Bráulio de Mendonça Filho. [...] A população operária da cidade é, naturalmente, avultada e como as fábricas sorocabanas aumentam sem cessar, essa população cresce continuamente. [As perfeitas condiçôes da cidade] atraíram operários de todos os outros centros fabris de São Paulo, e Sorocaba recebeu no seu seio bons e maus elementos. Como sempre acontece, os maus elementos passaram logo a ter ascendência acentuada sobre os bons [...] e a plácida vida de Sorocaba passou a ser seguidamente perturbada com greves. As primeiras greves foram coroadas de êxito: o patrão sorocabano estava no período difícil da organização e da experiência e, pouco afeito à vida industrial, entrou para o terreno das capitulaçốes. Foi um instante de fraqueza lastimável e o operariado sorocabano, açulou por propagadores de ideias avançadas, começou a tornar a situação das indústrias da cidade absolutamente insustentável. Os patrốes conheceram e era amarga das imposiçốes arrogantes, das reivindicações odiosas, dos atentados acintosos à disciplina, das depredações criminosas e estiveram a pique de serem vendidos na luta aberta pelo operariado. 
Esta passagem por si só nos revela várias informações e desmitifica outras. A primeira informação valiosa consiste na ratificação de que os operários se organizaram e reivindicaram com bastante vigor, ainda no período pré 1930 . Ademais, as diversas formas de reivindicaçôes, como as greves, depredaçóes etc., demonstravam um operário nada pacato e ordeiro.

A bibliografia sobre o período mostra o quadro de conflito entre patróes e trabalhadores na Primeira República. Renato Boschi, Eli Diniz, Edgar Carone, Gizlene Neder, Werneck Vianna e Angela de Castro Gomes, só para citar alguns, são unânimes ao perceber e problematizar a importância das greves dos trabalhadores, principalmente nas grandes metrópoles, como Rio de Janeiro, São Paulo, Salvador e Porto Alegre, que foram palco de grandes lutas por salários, redução da jornada de trabalho, direito às férias etc., coordenadas principalmente por anarquistas, nas duas primeiras décadas do século XX. Contudo, as reivindicações não se resumiam às greves, inclusive, gerais, pois comícios, passeatas, organização de Congressos, sabotagem em empresas, fundação de clubes, bibliotecas, jornais etc., caracterizavam, por conseguinte, uma situação de grande efervescência social. É neste quadro que entra o Estado, solicitado urgentemente pelos governantes da economia para mediar a relação com os governados. A solução foi a intervenção em todos os sentidos, inclusive com a criação das leis trabalhistas.

Vejamos na continuação da reportagem, a seguir, a posição da imprensa comercial já naquela época:

$\mathrm{O}$ delegado regional teve uma feliz inspiração: entrou em entendimento com os patrôes, venceu a indiferença de uns e a tibieza de outros e, resolutamente, aplicou ao operariado o sistema de identificação em uso na polícia de São Paulo. Contra a medida rebelou-se todo o operariado da cidade e as fábricas cerraram suas portas por tempo indeterminado. Passado o primeiro tempo de exaltação, veio a reflexão e a parte sã do operariado procurou o terreno amplo das negociaçôes. Foi repelido: as fábricas ficariam fechadas e só seriam reabertas com pessoal identificado na polícia. O operário sem reserva de dinheiro, com o crédito cortado pelo fornecedor, malvisto, pelas autoridades da cidade, deu de fechar os ouvidos à grita dos agitadores e, em pequenos grupos, demandou a delegacia de polícia. Medroso e humilhado passou pelo gabinete de identificação: a cordura dos funcionários policiais, a simplicidade das operaçóes, a palavra persuasiva do delegado regional foram vencendo as últimas resistências e as fábricas foram reabertas com todo o seu pessoal identificado.

Os maus elementos, que passaram pela identificação depuradora, foram postos à margem pelas fábricas e, baldos de recursos, vendo todas as portas impiedosamente fechadas, foram pregar em outras regióes industriais de Estado o seu sinistro evangelho. 
Sorocaba não conheceu mais greves gerais e os patrôes sorocabanos ficaram a salvo das antigas imposições humilhantes.

A transcrição acima revela o quanto a luta operária era tratada como um caso de polícia e referendada pelos jornais comerciais.

Reportagem do Jornal do Commercio, de 27 de outubro de 1925, nos dá o tom do grau de mobilização dos governados que, por um lado, fortemente organizados, tratavam os governantes em igualdade de condições e, por outro, da repressão que lhes acompanhou, demonstrando que a organização sindical era discutida no âmbito do direito criminal, um assunto para os tribunais penais. Por fim, a reportagem assevera sobre o medo das classes proprietárias das reivindicaçóes operárias:

A maior parte do operariado carioca está arregimentada. Há lá, por exemplo, a União dos Estivadores que é quase uma potência, a Aliança dos Operários em Fábricas de Calçados, a União dos Operários em Fábricas de Tecidos, etc, etc.

Em São Paulo, o geral do proletariado não tem associação de classes. A polícia paulista apurou que essas associaçốes são ninhos de agitadores, não operários, que vivem largamente à custa da crendice dos verdadeiros operários, e fecha-as sistematicamente, a bem da ordem pública.

O operariado carioca é quase todo ele nacional ou profundamente nacionalizado [...] por vezes trata os poderes públicos de igual para igual.

Em São Paulo [...] a nossa polícia lhe faz caçada sistemática e impiedosa, segregando-o nas prisóes, deportando-o, tirando-lhe o sabor de novas aventuras nesta parte do país, onde a parolagem não encontra eco.

Enquanto perdurar no espírito crédulo do operário a esperança da apregoada diminuição do custo de vida, ele se manterá calmo; mas a esperança cederá o passo às mais amargas desilusôes, e, então, as almas, que um sonho iluminava, estarão cheias de trevas - trevas onde virá luzir o velho e inextinguível clarão de ódio contra o patrão, que é a fonte do eterno mal.

Nesta mesma fonte documental, de 7 de setembro de 1918, exemplifica bem o quanto o operariado conseguiu se impor sobre as associaçóes dos patróes:

Efetuou-se ontem, no Centro Industrial do Brasil, uma grande reunião, convocada para ser dado aos industriais de tecidos o necessário conhecimento do acordo assinado pelas comissóes de industriais e operários, escolhidas para resolver sobre solicitaçóes feitas pela União dos Operários em Fábricas de Tecidos.

Compareceram os srs.: [...] (lista com mais de 40 nomes de industriais) [...]

As comissóes de industriais e de operários, abaixo firmadas e resultantes da reunião de 20 de agosto deste ano, efetuada na sede do Centro Industrial do Brasil, acordaram, unanimemente, no seguinte: 
1. - O Centro Industrial do Brasil, legítimo representante das fábricas brasileiras de tecidos, reconhece na União dos operários das Fábricas de Tecidos o órgão diretor e representativo da respectiva classe, cabendo, portanto, a esta União o direito de pleitear junto à Diretoria de qualquer fábrica de tecidos todas as coisas que digam respeito aos interesses dos seus associados. [...]

2. Qualquer que seja o adicional em vigor, sobre os salários atuais, ficará ele modificado para 30\% (trinta por cento), sendo extensivo às fábricas filiadas ao Centro Industrial do Brasil, nas quais, porventura, atualmente não exista esse adicional. Esse adicional vigorará enquanto perdurar a presente carestia de vida. 3. As fábricas filiadas ao Centro Industrial do Brasil, onde ainda não se observa o horário semanal de cinquenta e seis horas, ficam por este acordo obrigadas a adotá-lo desde já.

Por assim, haver combinados assinam o presente documento.

Rio de janeiro, 31 de agosto de 1918. [...] (lista com os nomes dos signatários.)

Pode-se inferir, a partir deste contrato de 1918 entre o Centro Industrial do Brasil e a União dos Operários em Fábricas de Tecidos, que os trabalhadores estavam bastante fortes e organizados, conquistando direitos históricos: como redução da jornada de trabalho; aumento salarial; e reconhecimento de seu sindicato como legítimo representante dos operários.

Como mostramos, existe uma contenda na literatura acerca da intervenção do Estado na regulação trabalhista. Para uns, foi bom para o proletariado, sendo uma exigência deste; para outros, foi resultado da característica autoritária da governança política, que queria ganhar o apoio dos trabalhadores; para uma terceira corrente, foi benéfico para as associaçóes dos empresários. A carta do presidente do Centro Industrial do Brasil, Jorge Street, em 1919, publicada em 13 de junho do mesmo ano no Jornal do Comércio, é reveladora. A epístola é longa, mas imprescindível para melhor entender o período (os grifos são nossos).

O grande industrialismo e o capitalismo moderno criaram para o trabalho e para os trabalhadores condiçốes novas e especiais, que tornaram inevitáveis graves divergências e antagonismos entre os trabalhadores e o patronato. Estas divergências foram agravadas pela absoluta dependência em que ficou o operariado em relação ao patronato, que detinha e detém em suas mãos uma grande parte senão a totalidade dos meios econômicos, sem os quais a outra parte dos operários não podem trabalhar e, portanto, ganhar o seu pão.

De fato, o machinismo que produz e transporta, assim como o dinheiro necessário para as compras das matérias-primas e para a movimentação comercial da produção, estão absolutamente nas mãos do patronato.

Daí resulta que os possuidores desses elementos regularam a sua vontade e de acordo com as suas vantagens e necessidades, todo o movimento da produção mundial. 
A duração do dia de trabalho estava nas mãos, assim como a taxa do salário era por ele regulada e marcada, segundo suas ideias e interesses. Se havia grande procura nos mercados, portanto, possibilidade de boas vendas, com bons lucros, era logo ordenado o dia 10, 11, 12 horas; se não chegava ainda, e a procura continuava, formavam-se turnos suplementares e o trabalho noturno era instituído. Isto durava enquanto as conveniências comerciais assim o exigiam. Se vinha a parada nos mercados, a cena mudava bruscamente. As turmas noturnas eram despedidas em bloco, as horas do trabalho diurno eram diminuídas e, se não bastava, eram reduzidos ainda os dias de trabalho.

As necessidades mesmo vitais do operariado não eram consultadas. [...] É um fato que a produção não tem sido regulada no mundo, sob o ponto de vista de garantir o maior benefício possível à coletividade humana, mas sim em vista dos maiores benefícios do capital, que detinha o poder de regular essas coisas. É certo também que a tendência natural do capital é impor o máximo de trabalho com o mínimo de salário.

Naturalmente, esse estado de coisas provocava e provoca o protesto do operariado. Mas, como se opor a estas condiçóes, como obter a melhoria da sua situação, e forçar o capital a concedê-las? Naturalmente, tratando e pedindo. Mas, o operário, tratando sozinho e desamparado do apoio de seus companheiros de classe, fica em situação absolutamente inferior à do patrão. $\mathrm{O}$ medo de perder o seu ganha pão tira-lhe a coragem de protestar ou pedir. [...]

Desta situação nasceu a necessidade das associações que se multiplicaram em toda a parte e cresceram com incrível rapidez, em número e poder.

A associação, nós bem sabemos, dá ao operariado coesão e meios de pedir, e de exigir, se necessário for, resistindo por longo tempo, pois a associação solidariza os operários da mesma indústria.

Assim, nós patróes, perdemos a vantagem de tratar só com os nossos operários isolados e fracos, e vamos ser obrigados a trabalhar com a associação, pelo menos tão forte como nós.

Assim, o contrato individual, com o nosso operário isolado, tem de ser substituído pelo contrato coletivo com essas associações.

É desagradável, eu concordo, mas é inevitável e, afinal, é justo.

O direito e a justiça da organização das classes operárias são, pois, indiscutíveis e os resultados obtidos por essas associaçôes em todo o mundo são extraordinários.

[...] naturalmente estas associações procuram inspirar ao operariado o sentimento de classe e solidariedade, que vai até o sacrifício, sob a fórmula de um por todos e todos por um. [...]

A própria legislação deve intervir para regular os direitos e deveres dessas associaçôes, assim como os das nossas, instituindo os necessários tribunais de arbitragem que, bem organizados, facilitaram muito a solução das questôes que não puderem ser solvidas por conciliação direta. 
O velho mundo já passou pelas fases de resistência e teve de ceder.

Nós devemos nos conformar com o inevitável e queimar as etapas que os outros já venceram. Isto me parece de boa e sã política para nós.

Eis porque eu entendo e comigo um bom número de industriais brasileiros que as associaçốes de classe dos nossos operários, quando legalmente constituídas e quando representem realmente em grande número de operários da sua classe, como é o caso da União dos operários de Tecidos - devem ser lealmente reconhecidas por nós, que com elas devemos tratar e resolver as questóes do trabalho que nos interessam.

Penso assim porque estou convencido de que hoje, no estado de alma mundial do operariado consciente de sua força e de seus direitos, as associaçóes de classe, nas condições a que nos referimos, longe de continuarem a ser fatores de perturbação de ordem, virão, pelo contrário, com o tempo, constituir elementos de ordem e grandes fatores de apaziguamento que facilitarão a solução de problemas graves oriundos da inevitável evolução econômico-social que se desenvolve por todo o mundo.

O novo Centro algodoeiro é forte e poderoso; é possível, pois, que ele consiga forçar seus operários à volta ao trabalho, mantendo os seus pontos de vista.

Terão obtido uma vitória de Pirro: terão, fiquem certos, operários com ódio no coração e o desejo de vingança na alma. Mas eu penso que isso não se dará; os meus colegas já têm abandonado muitos dos seus primitivos intentos e é provável que em breve tratem com a União, o que aliás, parece já estarem fazendo particularmente muitos que, quando reunidos, declaram solenemente ser um sacrilégio fazê-lo.

O tempo mostrará de que lado está a razão.

São Paulo, 9 de junho de 1919.

Podemos extrair desta carta muitas questóes sobre a conjuntura de 1919 no Brasil, e, particularmente, das especificidades da relação patrão-empregado. Primeiro, quem escreve a carta é o presidente da principal associação das indústrias do Brasil, mostrando não ser uma posição individual, mas, inclusive, majoritária dentre os industriais organizados no país, embora não seja unanimidade, pois diferentes posiçôes dos empresários ali coexistiam. ${ }^{5} \mathrm{O}$ industrial mostra um largo conhecimento das condiçóes objetivas do capitalismo e a absoluta dependência dos trabalhadores com relação aos proprietários, peculiar desse sistema. Ele reconhece o irrestrito poder do patronato sobre o trabalhador e que suas condiçôes de vida não são levadas em conta, como o total controle da jornada de trabalho pelos empresários que, de acordo com seus interesses comerciais, aumenta ou diminui a produção, afetando, consequentemente, o emprego. O que é por muitos teóricos ignorado, o industrial afirma com todas as letras: "a tendência natural do capital é impor o máximo de trabalho com o mínimo de salário” 
(Jorge Street, em 1919). Uma das constataçốes incide na ideia segundo a qual existem diferentes posições dos empresários, principalmente com relação ao reconhecimento dos sindicatos dos trabalhadores. Reconhece, também, o momento internacional de avanço do poder dos sindicatos. E, por fim, o mais revelador: defende que o Estado deva intervir na relação trabalhista com vistas a regular deveres e direitos de todas as associaçóes, tanto dos trabalhadores, quanto dos empregadores, devendo, ainda, criar tribunais de arbitragem para solucionar os conflitos que não forem solucionados diretamente. Tratava-se, portanto, de um clamor dos industriais ao Estado para intervir na relação capital-trabalho, regulando-a, já em 1919. Por último, o presidente da CIB ainda se mostrou um visionário ao perceber e defender que o reconhecimento dos sindicatos dos trabalhadores e a consequente negociação com eles, institucionalizando-os, arrefeceria sua luta revolucionária.

O mais importante a reter é que parcela dos industriais, em fins da década de 1910, como vimos no depoimento do presidente da CIB, já clamava pela intervenção do Estado, no sentido de controlar melhor os governados, garantindo a acumulação capitalista. É claro que a elaboração de uma legislação social significava para o empresariado, antes de mais nada, uma limitação das condições objetivas de realização do lucro livre de amarras. Portanto, possuía efeitos práticos e imediatos sobre a organização do trabalho e da lucratividade da empresa.

Como ratificação desta premissa, lembramos que os governantes da economia ocuparam ou possuíam forte influência em todos os conselhos/comissões para discussão e implementação de uma legislação trabalhista, enquanto os governados foram excluídos de qualquer participação. O trabalhador: 1) não participou dos conselhos/comissóes para elaboração de leis trabalhistas; 2) não tinha um corpo de representantes ocupando cargos eletivos na burocracia estatal. A partir destes dados, concluímos que só restara aos trabalhadores: a) aceitar a alta jornada de trabalho, salários baixíssimos, sem direitos trabalhistas; ou b) pressionar, reivindicando direitos e melhorias das mais diversas por meio da ação direta.

Por conseguinte, inferimos, muito facilmente, que a legislação do trabalho foi corolário das sugestóes dos governantes da economia, em absoluta consonância com as palavras do presidente da CIB, e dos governantes da política. Foram exemplos: 1) o projeto de código do trabalho que procurou coordenar e pôr em prática as leis e os projetos de leis já existentes sobre o assunto, desde o debate na Câmara Federal em 1917 (DINIZ; BOSCHI, 2004; GOMES, 1979; VIANNA, 1976); 2) o Conselho Nacional do Trabalho (CNT), encarregado, durante todo o período de 1924 a 1929, da discussão e elaboração do anteprojeto para reforma de leis e, também, 
de regulamentos que permitissem a entrada em vigor da nova legislação (GOMES, 1979).

Segundo Werneck Vianna, a Câmara passou a legislar aceleradamente em matéria trabalhista em 1919 - logo após as greves gerais de 1917 e 1919, em São Paulo, e, de 1918, no Rio, além de outros movimentos grevistas em outros estados da federação -, chegando ao ano de 1926 com boa parte das condiçóes de trabalho recoberta pela lei, como a dos acidentes de trabalho, a de férias e a do Código de Menores. Portanto, quatro anos antes de Vargas chegar à governança política.

Para efeito de sistematização da participação dos governantes da economia e dos governados na elaboração de políticas sociais no Brasil, nas primeiras décadas do século XX, podemos elencar os seguintes resultados: 1) a existência de extrema desigualdade de influência e representação junto ao Estado entre o empresariado e os trabalhadores, sendo aberta àquele e fechada a estes; 2) os interesses dos governantes da economia têm força dentro dos órgãos governamentais desde antes de 1930; 3) a implementação de uma legislação social tinha por objetivo básico conter as lutas sociais implementadas pelos governados; 4) a principal alternativa adotada pelos trabalhadores para impor na pauta a implementação de direitos sociais foi a ação direta (greves, passeatas, boicotes etc).

Em extrato, sob pressão dos governados foram criados direitos sociais. A regulação trabalhista foi posta em prática, pois os governantes da economia só aceitaram abandonar sua postura liberal - contrária à criação de direitos trabalhistas - em função da constante ameaça de seus lucros e de seu patrimônio por parte das greves, reivindicações, ações diretas e passeatas. Tudo isso associado a uma conjuntura internacional de luta revolucionária e de conquista de benefícios por parte dos trabalhadores em outras partes do mundo.

Em resumo, a situação para os governados era a pior possível. Tinham liberdade bastante limitada e poucos direitos trabalhistas, sendo estes amplamente desrespeitados. Em contrário a esta situação, os sindicatos tiveram forte atuação e conseguiram arrancar da governança política alguns direitos, apesar da forte repressão que sofreram. Em função das primitivas greves, os governantes da economia organizaram suas associaçôes coletivas e conseguiram demandar que o Estado exercesse o seu papel histórico: reprimir e controlar os trabalhadores combativos, garantindo melhores condiçóes de extração de mais-valor e de acumulação. Nestas condições, é mister destacar que até o presidente da principal associação coletiva dos empresários se sentia constrangido na insistência de sua classe em negar direitos aos trabalhadores. As greves e a organização dos governados foram fundamentais para tal fato raro. 


\section{CONSIDERAÇÕES FINAIS}

Diante da discussão bibliográfica, percebemos que uma interpretação socialdemocrata valoriza extremamente a criação de direitos para os trabalhadores, enquanto minimiza a repressão estatal e a manipulação sofrida pelos governados. A liberal, mais preocupada com as vantagens para o capital, foca nas condiçốes de obtenção de lucro para os empresários e normalmente ignora o papel exercido pelos governados e suas instituiçóes; quando a analisa, a vê como algo refratário, pois atuaria como empecilho para o pleno desenvolvimento do capitalismo. É neste interim, que os direitos trabalhistas são vistos como manirrotos.

Retomando as passagens de Viana (1951), ideólogo da governança política de Vargas, percebemos que vários intelectuais - com diferentes argumentos, ou simplesmente por não dizer o contrário - ratificam suas teses, segundo as quais os direitos trabalhistas foram criação benevolente do Estado (FRENCH, 2001; SCHNNEIDER, 2008; SANTOS, 1998; CARVALHO, 2001; FAORO, 2001; CARDOSO, 2003; SAISSE, 2005; PASTORE, 1994). Essas conclusões são sustentadas pelas opções teóricas-metodológicas de liberais e social-democratas que não privilegiam a luta dos trabalhadores por direitos. Atribuem a Vargas uma espécie de "pai dos pobres”, que, para o liberalismo, obstaculizou o desenvolvimento do país com as leis trabalhistas, e, para a social-democracia, diminuiu a dependência do trabalhador do mercado. Ambas desconsideram a força dos movimentos dos governados, suas greves, o histórico social, político e econômico da criação das leis, além da conjuntura internacional.

Como parte das interpretaçóes liberais, os brasilianistas Schnneider (2008) e French (2001), além de atribuírem um papel negativo às leis laborais, também defenderam que as mesmas foram criadas com o intuito de fortalecer o varguismo na peleja contra as oligarquias e os empresários, colocando, sem o menor amparo factual, os governantes da economia e o governo de Vargas em campos opostos.

O curioso desses argumentos consiste em conceber uma distância enorme entre governo político e associações empresariais. Como se aquele não tivesse qualquer compromisso com os donos do capital. É quase tratá-lo como insulado, um eremita, esquecendo, inclusive, os financiamentos de campanha, as grandes bancadas dos empresários, os ministros de Estado e, em diversas vezes, o próprio presidente da República como um legítimo representante do mundo do capital e assim se estabelecendo uma verdadeira plutocracia.

Outro fator negligenciado pela literatura liberal consistiu na ausência de uma simples questão: quais foram os atores elaboradores da legislação do 
trabalho? É importantíssimo entender que majoritariamente só os representantes do governo e dos empresários participaram da sua construção (WERNECK VIANNA, 1999; GOMES, 1979; DINIZ \& BOSCHI, 2004; COSTA, 1999; DELGADO, 2001; BOITO JR., 1999), materializando um modelo clássico de corporativismo estatal, excluindo os governados de qualquer indicação.

A característica central destas análises foi deixar de lado o papel exercido pela ação coletiva dos trabalhadores. Ao mesmo tempo, compreenderam o Estado como perdulário na defesa dos interesses dos governados e omitiram o atendimento prioritário das reivindicaçôes dos governantes da economia, donos do capital. Por consequência, suas críticas direcionaram-se para o excesso de leis trabalhistas, ou mesmo para a sua inadequação. Uma clássica interpretação liberal.

As interpretações social-democratas, por sua vez, incidiram em um anacronismo grave, caracterizado pela exaltação da governança política de Vargas e dos direitos por ela consolidados. Em oposto à perspectiva liberal, mas igualmente desprovida de realidade, veem o Estado como fiador dos interesses dos trabalhadores. Ler a administração Vargas com o olhar do século XXI, sob a hegemonia de políticas neoliberais - e, portanto, com flexibilização e/ou retirada de direitos - é bastante sedutor, pois desta maneira Getúlio apresenta-se como um excelente governante político. Esta, porém, constitui-se como uma leitura anacrônica.

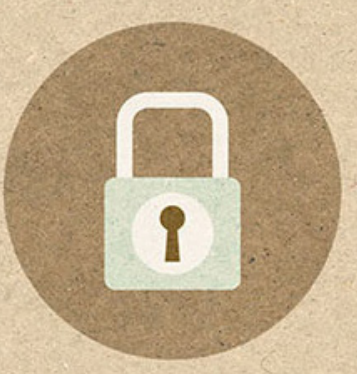

.............. 
Em resumo, as interpretações liberais e social-democratas, normalmente, tratam a lei pela lei, não levando em conta o contexto social. É uma questão de opção teórico-metodológica que deliberadamente relega as lutas dos governados por direitos. Um de seus equívocos centrais consiste no exame puro da lei, que perde sentido se não correlacionada com o âmbito político, econômico e social. Em outras palavras, examinar os direitos sociais por uma sequência cronológica de normas amplamente descontextualizadas e a-históricas, resume-se a um viés positivista.

Diferente das interpretações supracitadas, ressaltamos que os direitos sociais foram conquistados e tiveram como combustíveis as greves gerais de 1917, 1918 e 1919. Quando ampliamos nossos horizontes de análise com base em documentos históricos, podemos observar que, para a diminuição da jornada de trabalho no Brasil, a ação direta, as greves, passeatas, as dinamites do sindicalismo revolucionário e a organização dos governados foram fundamentais. A fundação do Partido Comunista do Brasil, as greves negras, as agitaçôes anarquistas, o movimento tenentista, a Coluna Prestes ${ }^{6}$, a imprensa e os clubes operários, as pressóes dos sindicatos na maior parte das vezes, são absolutamente ignoradas pela literatura do campo jurídico, da História e das Ciências Sociais no Brasil, resultando na exaltação de determinados governantes e retirando o protagonismo dos trabalhadores.

Estas vertentes interpretativaspreteriram o contexto internacional, no qual o governo Vargas estava inserido. Esqueceram de incorporar à análise, o avanço do movimento operário em todo o mundo, as revoluçóes socialistas, os movimentos anticoloniais, a crise do liberalismo, as deliberaçôes keynesianas, bem como a escolha pela intervenção estatal na economia nas potências europeias, nos EUA, e até em países da América Latina, como o México. Enfim, relutaram em entender a história de criação de direitos em toda parte como resultado das lutas sociais.

Ao olharmos por essa lente, vimos que essas questóes, indubitavelmente, minimizam a possível benevolência/ineditismo/coragem da governança política de Vargas. Por consequência, é salutar vislumbrarmos o varguismo como fruto da tendência mundial de intervenção estatal caracterizada pela criação de direitos trabalhistas em função das açóes diretas dos próprios trabalhadores organizados.

Por fim, é importante enfatizar que resgatar o contexto histórico e a importância das lutas sociais no Brasil para a criação de direitos para os governados é um compromisso metodológico. Além disto, trata-se também de dívida com muitos anônimos que foram assassinados, torturados, presos, extraditados, que abdicaram do convívio da família e de amigos, enfim, deram suas vidas para que, por exemplo, trabalhássemos oito horas por dia, embora tal "privilégio" esteja deveras raro. 


\begin{abstract}
Notas
1 Santos desenvolveu o conceito de cidadania regulada em 1979. Na década de 1990, ele revisou seu trabalho e o republicou em 1998, afirmando ter corrigido e atualizado muitas questões do trabalho anterior. É sobre a última publicação que tratamos nesta pesquisa.

${ }^{2}$ Ambos eram funcionários da FIESP.

${ }^{3}$ Ministro da Economia do governo de Jair Bolsonaro.

${ }^{4}$ Ver CARDOSO (2003).

${ }^{5}$ A postura do presidente da CIB em favor do reconhecimento dos sindicatos dos trabalhadores resultou em grande polêmica na organização patronal, inclusive com a saída de descontentes e a organização do Centro da Indústria de Fiação e Tecelagem de Algodão do Rio de Janeiro, em 1919. Ver Carone (1977).

${ }^{6}$ Ver PRESTES (1990).
\end{abstract}

\title{
Referências Bibliográficas
}

BOITO JR, A. Política Neoliberal e

Sindicalismo no Brasil. 2. ed. São Paulo:

Xamã, 1999.

. (2005b), O Sindicalismo na Política

Brasileira. Campinas: Editora da Unicamp.

BOSCHI, R. (1978), Elites Industriais

e Democracia. Hegemonia Burguesa e

Mudança Política no Brasil. Rio de Janeiro:

Editora Graal.

CARDOSO, A. M. A Década Neoliberal e a Crise do Sindicato no Brasil. São Paulo:

Boitempo, 2003.

\section{CARDOSO, F. H. Autoritarismo e}

Democratização. Paz e Terra: Rio de Janeiro, 1974.

CARONE, E. O Pensamento Industrial no Brasil (1880-1945). Rio de Janeiro: Difel, 1977.

COLLIER, R. B. \& COLLIER, D. Shaping the Political Arena: critical junctures, the labor movement, and regime dynamics in Latin America. Princeton: Princeton University Press, 1991.

COSTA, V. M. R. A Armadilha do Leviatã: A Construção do Corporativismo no Brasil. Rio de Janeiro: EdUERJ, 1999.

CARVALHO, J. M. Cidadania no Brasil: o longo caminho. Rio de Janeiro: Civilização Brasileira, 2001.

DE MORAES, W. S. Governados por Quem? Diferentes plutocracias nas histórias políticas de Brasil e Venezuela. Curitiba: Prismas, 2018.
DELGADO, I. G. Previdência Social e Mercado no Brasil: A Presença Empresarial na Trajetória da Política Social Brasileira. São Paulo: LTr, 2001.

DINIZ, E. Empresário, Estado e Capitalismo no Brasil: 1930/45. Rio de Janeiro: Paz e Terra, 1978. \& BOSCHI, R. Empresários, Interesses e Mercado. Dilemas do Desenvolvimento no Brasil. Belo Horizonte: Editora UFMG/Rio de Janeiro: IUPERJ, 2004.

DREIFUSS, R. A. 1964: A Conquista do Estado. Petrópolis: Vozes, 1981.

FAORO, R. Os Donos do Poder: Formação do Patronato Político Brasileiro. São Paulo: Globo, [1958] (2001).

FARINHA NETO, O. (2007).Atuação libertária no Brasil: A federação AnarcoSindicalista. Rio de Janeiro: Achiamé. FERREIRA, J. (Org.). O populismo e sua História. Rio de Janeiro: Civilização brasileira, 2001.

FRENCH, J. D. Afogados em leis: a CLT e a cultura política dos trabalhadores brasileiros. São Paulo: Editora Fundação Perseu Abramo, 2001..

GOMES, Â. C. O populismo e as Ciências Sociais no Brasil: notas sobre a trajetória de um conceito. In: FERREIRA, Jorge (Org.). O Populismo e sua História. Rio de Janeiro: Civilização Brasileira, 2001. 
Burguesia e Trabalho: política e

legislação social no Brasil 1917-1937. Rio de Janeiro: Campus, 1979.

MARX, K. Introdução à Crítica da Economia Política. In: MARX, K. Manuscritos econômico-filosóficos e outros textos escolhidos. São Paulo: Abril (Coleção Os Pensadores), 1974.

MORAES FILHO, E. O Problema do Sindicato Único no Brasil: seus fundamentos sociológicos. São Paulo: Alfa-Ômega, [1952] (1978).

NEGRO, A. L \& GOMES, F. S. As greves antes da "grève": as paralisações do trabalho feitas por escravos no século XIX. Ciência e Cultura, v. 65, n. 2, p. 5659, 2013. Disponível em: https://dx.doi. org/10.2180o/Sooog-67252013000200023. Acesso em: 12 dez. 2018.

NEGRO, A.L. \& GOMES, F. S. Além de senzalas e fábricas: uma história social do trabalho. Tempo Social, v. 18, n. 1, p. 217-240, 2006. Disponível em: https://bit. ly/3bMxdJ1. Acesso em: 12 dez. 2018.

OLIVEIRA, F. Crítica à Razão Dualista: O Ornitorrinco. São Paulo: Boitempo Editora, 2003.

PASTORE, J. Flexibilização, Mercados de Trabalho e Contratação Coletiva. São Paulo: LTr, 1994. 1997.

. A Agonia do Emprego. São Paulo: LTr,

PRESTES, A. L. A Coluna Prestes. São Paulo: Brasiliense, 1990.

RODRIGUES, E. ABC do sindicalismo revolucionário. Rio de Janeiro: Achiamé, 2004.

SAES, D. República do Capital. São Paulo:

Boitempo, 2001.
SAISSE, S. A Regulação do Trabalho no Brasil: obstáculo ao aumento da renda e do emprego. Brasília: CNI, 2005.

SAMIS, A. et al. História do Movimento Operário Revolucionário. São Paulo: Imaginário; São Caetano do Sul: IMES, Observatório de Políticas Sociais, 2004.

SANTOS, W. G. Décadas de Espanto e uma Apologia Democrática. Rio de Janeiro: Rocco, 1998. . Cidadania e Justiça. Rio de Janeiro: Campus, 1979.

SCHMITTER, P. C. Still the Century of Corporatism?. Review of Politics, v. 36, n. 1, 1974.

SCHNEIDER, B. R. (2004a), Varieties of Semi-Articulated Capitalism in Latin America. In: Annal Meeting of the American Political Science Association, Chicago. Manuscrito [...] Chicago: APSA, 2004a.

Business politics and the state in twentieth-century Latin America. Cambridge: The University Cambridge Press, 2004b.

. Comparing capitalisms: liberal, Coordinated, Network, and Hierarchical Varieties. Manuscrito, 2008.

VIANA, F. J. O. Direito do Trabalho e democracia social (o problema da incorporação do trabalhador no Estado). Rio de Janeiro: José Olympio, 1951.

VIANNA, L. W. Liberalismo e Sindicato no Brasil. Belo Horizonte: Editora UFMG, 1999. WEFFORT, F. O Populismo na Política Brasileira. 4. ed. Rio de Janeiro: Paz e Terra, 1980.

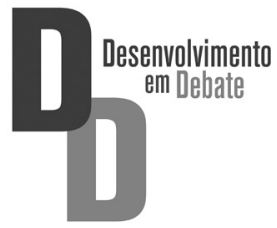

